\title{
Rebellious and Strong Black Women in Paradise
}

\author{
Zadmehr Torabi (Ph.d Candidate), \\ Parvin Ghasemi (Professor of English Literature) \\ Shiraz University, Shiraz, Iran \\ E-mail address: zadmehrtorabi@gmail.com, pghasemi54@gmail.com
}

Keywords: Toni Morrison; Paradise; Bell Hooks; Alice Walker; Black Feminism; subalterns

\begin{abstract}
The main aim of this paper is to apply black feminist tenets especially those of Bell Hooks and Alice Walker to demonstrate that unlike the passive black female characters of The Bluest Eye, and the resisting but finally victimized black women of Beloved, the wise and strong black women of Paradise who live in the Convent, are strong enough to recreate themselves as subjects, and to cultivate their own unique identity in a hegemonic environment which is replete with racial and gender discrimination. Black feminist actions and womanistic rituals help them accomplish this improvement. Consolata, and Mavis are two of such strong women of the Convent who not only succeed in healing themselves, but also in healing other black women as well. Black feminists claim in order to place black women at the center of stories about the American past, they must be depicted as subjects, that is, as creative change-agents, rather than as objects, or victims of hegemonic agency. In Paradise black women are depicted thus, have their own voices, and completely reject the patriarchal ideology.
\end{abstract}

\section{INTRODUCTION}

In Paradise, Morrison focuses on the color prejudice of the dark-skinned people of Ruby toward less dark-skinned women. The town of Ruby's leaders are especially fearful because the women who have taken refuge in the Convent "don't need men and they don't need God," at least not the patriarchal Christian God that these men follow (Morrison, 1997: 276).

Ruby's people are the descendants of a group of ex-slaves who, due to their poverty and the "coal black" (Morrison, 1997: 160) color of their skin, were constantly rejected by already existing communities; both white as well as less black skinned ones, in the Western United States. Though the Founding Fathers of Ruby decide to create their own town, called Haven, where they can raise and educate their children in a place free from racial prejudices, however, as Jeannette King observes, "In trying to create a safe haven beyond the reach of white racism, they create a world which ironically becomes dependent on the same kind of binary oppositions that underpin white supremacist thinking" (2000: 155-156). Moving farther from their ideals, the Founders inadvertently make a racist and sexist community. While the Founders' offspring eventually move away from Haven and create Ruby, the tensions and hypocrisies begun by their forefathers remain with them.

The Ruby men's obsessive focus on the injustices of racial discrimination they have suffered leads them from the position of victim to that of victimizers of the less black women, and this makes the women decide to move to the Convent, and maintain a space that is psychically and physically safe.

Seventeen miles from the town, migratory women from Ruby establish a multiracial community in a former convent, and as Peter Widdowson writes the Convent women demonstrate "refusal to accept crude ("black and white") binaries and stereotypes" (2001, 313). The women gathered at the convent, led by Consolata, live outside the authority of the founding black fathers of Ruby, and the Ruby men decide this outrageous independence must be suspended. This determination culminates in an armed group of Ruby men that goes out to the Convent and battles the women. The battle between the Ruby men and the Convent women demonstrates the women's courage, bravery and self-assertion against the men. The battle continues with the Convent women 
and Ruby men injuring one another. However, because the men of Ruby that attacked the Convent women were armed, finally the nine 8-rock men murdered five Convent women: Consolata, Mavis, Pallas, Seneca, and Gigi, and of course "they shoot the white girl first" (Morrison, 1997: 3).

Furthermore, although the men of Ruby eventually kill the residents of the Convent, Paradise concludes with the possibility that the Convent women continue to dwell and remain unvanquished, maybe in the guise of ghosts.

Paradise illustrates how these women assert and accomplish meaningful agency by repudiating the norms of the dominant Ruby and how they stand against black patriarchal culture. In other words, it illustrates how the African American female identity could be reconstructed through black feminist or womanistic recourse to its own cultural heritage and by a quest of somewhere to rest, plan, and to call "home'" in a domineering land.

\section{BLACK FEMINISM}

\subsection{BELL HOOKS}

Bell Hooks believes black feminists are social thinkers and activists who are able to rise above their own experiences and to challenge black women with a new view of oppression and black female identity, a view that has the possibility of changing the world. Hooks also claims that until now the black women have been silent under unjust charges of white men and women against them and white women have always protested against the admission of colored women into any national organization on the ground of their dark skin color and their alleged immorality. Therefore Hooks believes now it is time to write about who really the colored women are and hope to become. Hooks also believes a problem of the concept of the universal woman, maintained by the white feminists, is that it neglects differences such as race and class of women, and in that displacement whiteness often operates as a norm against which all other women are measured. In this regard, Judith Butler believes: "the insistence upon the coherence and unity of the category of women" refuses the "multiplicity of cultural, social, and political intersections in which the concrete array of women are constructed" (Meade, 2004: 113).

Also according to Hooks:

While an awareness of male power to rape women with impunity in a patriarchal society is necessary for woman's survival, it is even more important that women realize that they can prevent such assaults and protect themselves should they occur. (1982: 68)

\subsection{ALICE WALKER}

Alice Walker, coined the term "Womanist" to describe courageous women who like Baby Suggs in Beloved, and most women characters in Paradise want to know more and in greater depth than is considered proper for them. She defines a "womanist" as a woman who loves being a woman and enjoys the company of other women (Walker, 1983). It also refers to a woman who prefers women's culture, and a woman who is committed to the wholeness of entire people, male and female. Although black feminists have utilized the notion of womanism to describe their thought and activism, it is not separate from black feminism, because it is based upon the experiences of women of color and aims to end inequalities, not just for black women, but for all people.

Black feminists like Hooks, and Walker argue that in order to place black women at the center of stories about the American past, they must be depicted as subjects, that is, as creative change-agents, rather than as passive objects. This paper asserts that Morrison does this in Paradise in which we see the Convent black women do not accept to be forced to assimilate into the mainstream white or black patriarchal standards. 


\section{DISCUSSION}

\subsection{The Bluest Eye, and Beloved vs. Paradise}

Comparison of the Convent black women in Paradise with the black women in The Bluest Eye, and Beloved will give a clearer image of the Convent women. While the female slaves in The Bluest Eye, and Beloved, "lived in constant awareness of" their "sexual vulnerability and in perpetual fear that any male, white or black, might single them "out to assault and victimize", in Paradise, the convent women have managed to get secure from this fear and worry (Hooks, 1982: 24). Bell Hooks claims in much of the fiction by contemporary black women writers, the struggle by black female characters for subjectivity, "usually takes the form of black women breaking free from boundaries imposed by others, only to practice their newfound "freedom" by setting limits for themselves. Hence though black women may make themselves "subjects" they do not become radical subjects. Often they simply conform to existing norms, even ones they once resisted"'(1992: 47). This paper demonstrates that Paradise women become radical subjects and agents in the Convent, and discusses that more than other novels by Morrison, Paradise chronicles the attempts by black females to constitute radical black female subjectivity. The Convent women challenge every restriction imposed upon them, and transgress all boundaries, they have substituted selfloathing by self-loving and thus reclaim their African American female identity.

Black women and girls in The Bluest Eye, are victims of rape, murder, and parental abuse, while they are more or less passive and weak to take a constructive action to save themselves. Beloved illustrates how black women can survive and proceed in a world where they are victims of racial and gender discrimination. Though Beloved women are less passive than the women of The Bluest Eye, and they begin their quest for freedom and salvation, even they finally feel fragmented, lost, and almost unwanted. Each one of the black women or girls in The Bluest Eye is a helpless victim and a resisting victim in Beloved and in no position to do anything positive about their problematic condition. But in Paradise, hidden or underlying black feminist resistance becomes a manifest battle against the Ruby men, and their hegemonic patriarchal discourse.

Moreover, racial self loathing exists in The Bluest Eye, and in Beloved, but not in Paradise. In The Bluest Eye Pecola hates her own appearance and Pauline hates Pecola, and in Beloved, though benevolently, Sethe kills Beloved, but in Paradise, Convent women by the help of black feminist tenets learn to love themselves, reject the patriarchal social structures, and fight back armed Ruby men who have come to kill them. In The Bluest Eye, and Beloved black women live in social contexts that impose upon the displaced African American women the identity of "sexual savage" and as white slave owners adopted a self-righteous sexual morality for themselves, they stereotyped the black women as sexually loose. Thus, in the two novels, black women were considered as sexual temptresses and accused of leading men away from spirituality into sin. In The Bluest Eye, and Beloved, the black female body was considered as a mystery to be solved by the white slave owners. In the two novels especially in the first one, men were active and women appeared passive, men looked at women and women were being looked at, thus the black women unconsciously and gradually turned into objects. Such a case is not true for Paradise women who accomplish their aim in being no longer victimized or unrecognized. In Beloved it is a man, Halle who manages to buy his mother's (a woman's) freedom for her, in Paradise the women escape from Ruby and free themselves from patriarchal bondage.

The destructive impact of white supremacy on the black female psyche has been well depicted in The Bluest Eye, Beloved and in Paradise, but constructive revolutionary acting against this impact occurs only in Paradise. This paper argues that in Paradise the Convent women move beyond their marginal status as objects and they interrogate and subvert the social paradigms by resisting the dominant discourse's cultural inscription on them. They end their bondage to that discourse by recreating themselves with their own black feminist strategies of resistance.

Paradise is the narration of the experiences of some women who were "subalterns" in Spivak's terms, that is they were simultaneously subjected to male domination and racial subjugation, and who finally overcome their exploiters to recreate themselves as agents and 
subjects. In other words, black women in Paradise undergo alterations to emerge as committed revolutionary subjects. Speaking about her commitment to revolution, Angela Davis notes:

For me revolution was never an interim "thing-to-do" before settling down: it was no fashionable club with newly minted jargon, or a new kind of social life- made thrilling by risk and confrontation, made glamorous by costume. Revolution is a serious thing, the most serious thing about a revolutionary's life. When one commits oneself to the struggle, it must be for a lifetime. (Hooks, 1992: 59)

Bombarded with images representing black female bodies as sites of exploration, black women have either passively absorbed this thinking as in The Bluest Eye or rebelliously resisted it as in Paradise. Convent women "'challenge assumptions that the black body, its skin color and shape," are signs of shame and sites of exploration (ibid, 63).

They also challenge the ideology that turns a black woman's body into an 'ideological site, a space where a variety of discourses cross and converge"' and the condition that 'her body is written on by discourses of power and domination manufactured in a white supremacist society' (Jozwiak, 2001: 189).

In Paradise we observe that Morrison portrays how African American women might have houses, but not homes. Haven, this group's first settlement, and then Ruby fail to be ideal places because the racial ideologies that the inhabitants of Ruby sought to escape from, follow them within their hearts and minds. Paradise thus illustrates the difficulties of building a real home within the racialized social contexts of the United States. Understanding these issues leads to the creation of "safe spaces." Safe spaces are "social spaces where black women speak freely" (Collins, 2000: 100). In order for the oppressed group to continue to exist as a social group, the members must have spaces where they can express themselves apart from the hegemonic or ruling ideology. In Paradise, unlike what we saw in The Bluest Eye, and in Beloved, this space almost exists for the Convent women who have a space in which according to Morrison a woman can walk out of home at night without any fear of being attacked. According to Hooks, to reach such spaces black women have been struggling for a long period of time:

Yet all through the darkest period of the colored women's oppression in this country her yet unwritten history is full of heroic struggle, a struggle against fearful and overwhelming odds, that often ended in a horrible death. (1982: 2)

Therefore, while the social marginalization caused by institutionalized racism still exists in Paradise, the black women in the novel have not internalized racism, and courageously stand against patriarchy and racism in discursive social contexts. Krumholz believes the Convent women

carry no ideals of family or society in their wanderings, but together they tackle the anxiety of belonging and create an open house by challenging the social and historical strictures that surround them and by confronting the scary things inside themselves. (Krumholz, 2002: 21)

Traditionally, all black women of The Bluest Eye, and Beloved, "irrespective of their circumstances, were lumped into the category of available sex objects" (Hooks, 1982: 58). In Paradise the Convent women defy this condition and become agents with their own identity. Their deeds are a direct challenge to patriarchal and racist notions about the inherent inferiority of black women, and they demonstrate that given the same opportunities as whites they can succeed in all areas.

While the black women in Beloved believe some day their social regeneration will occur, black women in Paradise take actions and create that regeneration and this helps in solving their problems of race contact and cooperation.

\subsection{EXPRESSION OF RADICAL BLACK FEMALE SUBJECTIVITY IN PARADISE}

As Channette Romero writes 'The Convent women learn to empower themselves without needing to adhere strictly to male patriarchal control or a rigid belief system predicated on division and hierarchy' (2005: 420). It will be conducive for the aim of this study to note that in 1998, the 
Texas prison authorities banned Toni Morrison's Paradise from Texas prisons because the prison authorities believed it contains racial information that might be regarded as written for communicating information designed to encourage strikes in prisons.

The Convent women have all rebelliously escaped from what Bhabha would call "unhomely" dangerous spaces. In Paradise the subjugation of black women in different aspects, for example their inability to gain control over their bodies has been a primary impetus behind their rebellious deeds, and they bravely fight to obtain complete control over their bodies and identities.

The Convent women, rather than remaining passive about the discriminations they face, speak with confidence about what they can do to improve their lives. They are not brainwashed by the US patriarchal and racist social system, and this is why they accomplish in overthrowing the system in their Convent community.

\subsection{CONVENT WOMEN ACT AS THEY WISH}

The women from the Convent dress as they wish: Mavis, Gigi, and Seneca, appear at the wedding of K.D. and Arnette. They are provocatively dressed, "looking like go-go girls: pink shorts, skimpy tops, see-through skirts... obviously no underwear, no stockings" (Morrison, 1997: 156). After the wedding, the girls dance, "throwing their arms over their heads" (ibid, 156). Convent women are not afraid of violent conflicts that could happen as a result of their efforts to establish a utopia, which is why they attempt to construct a place which could act as a model of cultural and social collectivity. It is interesting to note also that in the Convent the women have their own road "It was women who walked this road. Only women. Never men"' (ibid, 270).

And some of them learn to drive even at an old age, in one scene Lone screamed joyfully because "'finally, at seventy-nine, unlicensed but feisty, she was going to learn to drive and have her own car too"' (ibid, 270).

According to Hooks "The reality is that many black people fear they will be hurt if they let down their guard, that they will be the targets of racist assault since most white people have not unlearned racism' (1992: 16) but the black women in the Convent are not afraid of taking new roles in discursive social contexts. They know that 'loving blackness as political resistance transforms"' their "'ways of looking and being, and thus creates the conditions necessary for' them "to move against the forces of domination and death and reclaim black life", (ibid, 20).

Convent women are not afraid to transgress boundaries, to take risks, and to deride the fact that it is difficult for black women to recreate their own identity in white supremacist capitalist patriarchy. Most of them, as it will be soon discussed in more detail, frequently assert themselves as active subjects. They rebel against enforced domesticity, in other words domestic slavery, and assert the primacy of female friendship, they attempt to break with patriarchal male identification and lose the friendship of those conservative friends who have surrendered to convention.

Hooks believes

Radical black female subjects are constantly labeled crazy by those who hope to undermine our personal power and our ability to influence others. Fear of being seen as insane may be a major factor keeping black women from expressing their most radical selves. (1992: 54)

The Convent women urge those who oppress black women, to confront the consequences of their actions, and to know that in Gates' view tolerating each other is also very important and society won't survive without it, in other words "cultural tolerance comes to nothing without cultural understanding" (Kjelle, 2004: 67).

The Convent women know the feminist premise that "happiness and power come to women who learn to beat men at their own game, to throw off any investment in romance and get down to the real dog-eat-dog thing'"(Hooks, 1992:69). They express their radical black female subjectivity by confronting the cliché representations of their sexuality as a burden they must suffer, and they succeed in making "'the oppositional space where" their "sexuality can be named and represented, where' they are not sexual objects, and where they are no longer brainwashed and trapped (Hooks, 1992: 77). 
Black feminists believe 'black woman and black man are unable to respond fully to one another because they are so preoccupied with the white power structure, with the white man' (ibid, 104) and this condition is what we encounter between Convent black women and Ruby black men. In other words, solidarity between black women and men continues to be undermined by sexism and misogyny.

\subsection{REBELLIOUS AND STRONG CONVENT WOMEN}

Gazing also has been a medium of resistance for colonized black women. The historical attempts to repress black peoples' right to gaze had produced in them a strong desire to gaze with opposition, and this desire reaches its climax and is accomplished for the Convent women. For them spaces of agency exist wherein they can interrogate the gaze of the men. According to Hooks: "Subordinates in relations of power learn experientially that there is a critical gaze, one that "looks" to document, one that is oppositional" (1992: 116). Moreover, the black women of the Convent know that how they see themselves in the Convent is most important, not how they will be stared at by others.

The Convent women led by Consolata have understood that white imperialist racist ideology has cut bonds between African Americans and their historical roots. This helps them to gain a rebellious gaze at their surrounding and create an alternative community for themselves. Magali Cornier Michael believes

In a utopian gesture, Paradise depicts an alternative community of women actualized through coalition processes; at the same time, however, the novel examines the ways in which this group of women threatens the dominant societal structures that remain patriarchal and hierarchical. (2002: 644)

Black women of the Convent struggle to end negative images of black womanhood which were perpetuated by Ruby men as well as the whites and attempt to overthrow the myth that all black women are sexually loose, and they demonstrate that once the social restraints on black women have been eradicated, they will be as autonomous and self-determining as men. Moreover, the Convent women are like traditional Amazons who were a group of women who joined together to promote female self-government. Diner writes of Amazonic women:

Amazons deny the man, destroy the male progeny, concede no separate existence to the active principle, reabsorb it, and develop it in themselves in androgynous fashion

female on the left, male on the right. (Hooks, 1982: 82)

According to black feminism fear of being lonely or unloved, had caused women of all races to accept gender discrimination, however, in Paradise convent women are courageous and rebellious and are not afraid of loneliness and such conditions. They openly confront gender discrimination and armed racism of Ruby men to the point of death.

Convent women go on to heal the wounds suffered as a result of maternal neglect and struggle to create a new way of seeing and interacting with the world around them, recognizing their individual responsibilities for creating better communities, and seeking, above all, a society that sustains people regardless of gender, race, class, ethnicity, or sexuality.

Before the attack on the Convent, the Convent women are represented as women who are no longer brainwashed by the patriarchal hegemony of Ruby; they dance in the rain, symbolically washing away their fear and pain. The Convent women by rejecting the patriarchal ideology, and free from the laws and traditions of Ruby, "are the ultimate outsiders, and thus a threat to the community the men have worked their entire adult lives to build"' (Beaulieau: 266).

Awareness of one's own subjectivity, which is a feminine goal, has become finally feasible and accomplished in Morrison's novel, Paradise, and for black women of the Convent. Julia Kristeva believes femininity is marginalized, and oppressed, just as the working class is marginalized and oppressed (Tyson, 2006: 103). However, at the end of Paradise the experiences of women of color, and poor, undereducated women in the Convent is not undermined, and the 
Convent women are not victimized by any oppressive force, whether the force be racial, gender or class discrimination.

The Convent women who are neither farm slaves, nor domestic and kitchen slaves, successfully turn an embezzler's pornographic house into a feminized, matriarchal space and into a black feminist Convent, and into a true haven for the town's black female castoffs, and it becomes a shelter from the excesses of black patriarchy. In Hooks' terms, the convent women turn their "marginality" into "a site of resistance, as location of radical openness and possibility" (1990: 22).

Each of the Convent residents, Mavis, Gigi, Seneca, and Pallas, comes to the Convent because she escapes from a painful aspect of her past. As Raynor claims what Paradise does is to". .. give voice to the voiceless and record a history of a people, especially ordinary people, "who have been ignored or purposely forgotten" (2007: 177).

According to Ghasemi, in Paradise, 'By resisting to conform to the definitions imposed on them as stereotypes and rejecting the socially accepted notions of motherhood," the Convent women 'refuse to be solely their children's nurturing sources and by showing an awareness of the options open to them, they are able to recognize the value of their own individuality (2012: 478).

The Convent women even remove Christian iconography from the Convent building, as one of the male invaders notes that on the wall, "Clean as new paint is the space where there used to be a Jesus" (Morrison, 1997: 12). The destruction of Catherine of Siena's image by the Convent women represents the destruction of a patriarchal ideology in which women are slaves to patriarchal Christianity. Actually the fact that Catherine of Siena's image is destroyed is a deconstruction of oppressive Christian thought, even when that image is of a "feminist" saint. Thus, the Convent women begin a gendered cultural war to the hope of creating an earthly paradise, and it is for this reason that the novel opens in dystopia, "They shoot the white girl first. With the rest they can take their time" (ibid,3).

It will be a huge work to analyze all the Paradise women in terms of their strength and rebelliousness, and the reason is that there are many women in the novel that can be categorized as rebellious and strong. In this regard, Craig S. Womack writes:

Paradise, with its huge cast of characters - I lost count after sixty - abandons the tradition of a single literary protagonist to opt instead for an entire community as its focus, the towns of Haven and Ruby. (2009: 20)

However, in the following parts, the most outstandingly wise, strong, and rebellious Convent women will be discussed:

\subsubsection{CONSOLATA (CONNIE)}

After years of drunken decline, Connie has an awakening, takes her full name (Consolata Sosa), and begins to remake the female community at the Convent. The Convent women begin to decolonize their minds when Connie claims: "I call myself Consolata Sosa. If you want to be here you do what I say. Eat how I say. Sleep when I say. And I will teach you what you are hungry for" (Morrison, 1997:262). In this passage, Connie renames herself Consolata, which symbolizes an effort to recreate herself and subvert the colonialist ideology that has marked her body and mind.

Consolata leads the Convent women into a new sense of purpose and life. She instructs the women to paint images of themselves, and their fears on the basement floor, and begins to lead them into sessions of womanistic loud dreaming that allow them to exorcise the ghosts that haunt them by telling their stories to each other (Beaulieau, 265). She teaches the women who come to live with her how to practice a way of life that could improve their mental and physical well being. Consolata wants to awaken the black women so that they would not only oppose the injustices of racist domination, but be so moved that they would engage in anti-racist struggle.

Throughout the novel, Consolata functions as a sort of Christ figure. The women view her as someone who accepted each black woman as she was and who acted as an ideal parent, friend, and companion in whose company the black women were safe from any harm. Like Christ, she revives two individuals who have crossed over into death. Infused with her own divinity, she prepares a 
special meal for the women - a sort of Last Supper-and then like Christ she invites the women on the journey of self discovery.

Her dictum that mind and body must be valued equally thus stands as her foundational lesson for the women: "Hear me, listen. Never break them in two. Never put one over the other. Eve is Mary's mother. Mary is the daughter of Eve"(Morrison, 1997:263). Thus, the chief cause of the transformation of the Convent from house to home is Consolata, who plays the role of the Convent wise women and almost a mother to the Convent women.

\subsubsection{MAVIS ALBRIGHT}

Mavis Albright is the brave woman whose arrival in 1968 turns the Convent into a safe haven for wayward women, some on the run from men or the law, some searching for something or someone. After the battle with her husband, Mavis intentionally leaves the house through the front door, "did not look toward the kitchen and never" returns to it again (ibid, 27). Mavis has understood this fact about men that most men, both white and black, will only respect those women who oppose their subjugation, and acknowledge as equals those who will not submit to their rule. Obviously, this black feminist knowledge is essential for the freedom of Convent women.

\subsubsection{PATRICIA}

Like other Convent women, Patricia is not brainwashed by the dominant discourse of society and knows that "Emptying themselves of internal conflicts, Europeans located their own rejected parts in "others," identified as enslaved Africans, who became black in European eyes in order for Europeans to become white"' (Morrison, 1992:34).

\subsubsection{GIGI}

Gigi is one of the Convent women who is rebelliously fond of sunbathing naked and wearing few clothes.

\section{WOMANISM AMONG THE CONVENT WOMEN}

The Convent women are depicted in a way that reminds one of Alice Walker's definition of womanism:

sociable and connecting when they spoke to you, otherwise they were still and appraising. But if a friend came by, her initial alarm at the sight of the young women might be muted by their adult manner; how calmly themselves they seemed. (Morrison, 1997:265-266)

Moreover, the Convent women are not brainwashed by the cliché that men are naturally more domineering, while women are seen as nurturing, child rearing and domestically inclined. As it was briefly discussed, they rebelliously follow their own minds, and do as they please.

Consolata begins the process of womanistic loud dreaming at the Convent when she speaks to the other women of her past. The process

involves the women telling each other their stories in the form of loud dreaming, which is... willingly sharing and experiencing each other's painful stories, histories, and dreams and with their bodies and psyches simultaneously, they provide for each other unmatched nurturing support. (Magali, 2002)

The loud dreaming at the Convent is a social process of womanistic healing to heal the Convent women's psychic wounds and to recreate their identity as subjects or agents. The Convent women are able to heal each other collectively by first articulating their traumas and then learning to recognize and love the connections between themselves and other women. As Dalsgård writes 'Once the women are coherent and strong and clean in their interior lives, they feel saved' (2001: 233).

However, the women learn to heal themselves through confronting and sharing stories of their traumatic pasts. This point is especially applicable to Billie Delia who takes refuge in the Convent 
after she fights with her mother, and her memories of her stay there demonstrate how intertwined physical and psychic healing are:

They had treated her so well, not embarrassed her with sympathy, had just given her sunny kindness. Looking at her bruised face and swollen eyes, they sliced cucumber for her lids after making her drink a glass of wine. No one insisted on hearing what drove her there, but she could tell they would listen if she wanted them to. (Morrison, 1997: 308)

\section{WHAT IS THE SOURCE OF THE CONVENT WOMEN'S POWER?}

According to tenets of black feminism and womanism, the Convent women are aware that dependency of a woman on a man for definition of her own identity leads to her emotional breakdown when she feels unloved or neglected, the reason being that without him, she lacks her center of being. Morrison, a responsible black feminist, has also suggested the potential solution for black women's self recovery. Her proposition says that black women must take pride in their color and their gender. They need to be reliant upon other females of the community for self-fulfillment and for identification with their own selves. Female friendship not only helps black women to cope with the dehumanizing effects of patriarchy, but it also heals them emotionally. Mutual understanding and affection between black women can help them survive the discursive systems of oppression, fight against them and ameliorate the conditions of society. In Hooks' words a black woman 'Without the distortions ... is a healthy, attractive looking woman who in no way resembles white people's negative stereotype of black women (1982: 65).

Convent women also feel empowered by God's protection and they know how to respect and empower themselves since they believe: "not only is God interested in you; He is you" (Morrison, 1997: 147. original italics).

\section{CONCLUSION}

The development of Morrison's female characters from weak and passive stereotypes of women in The Bluest Eye to assertive, decisive, and rebellious women in Paradise, indicates that the Convent women of the Paradise do not limit themselves by blindly obeying the cliché norms of black maternity and matriarchy which assume certain cliché qualities attached to black women. The Convent women's replacement from Ruby to the Convent is generally regarded to be a flight from oppression to freedom, by which they seek to maintain their own identity in spite of the socially defined notions of conventional motherhood. Thus, the assertive women of the Convent, deconstruct the old image of black women's passivity and seclusion, and exhibit their humanity by exercising decisiveness and self-defense. Finally they succeed in decolonizing their minds from racial and patriarchal oppression as they free themselves from white and black paradoxical and hegemonic patriarchal norms imposed on them.

In Paradise, gender discrimination and racism are systems of societal and psychological restrictions which have affected the lives of the Convent women, but the restrictions have not succeeded in brainwashing their psyche and in demolishing their identities. Therefore, the novel also urges a scrutiny of the African American concepts of gender, race, and nation. That is why 'Convent women subvert the white supremacist ideology that defined black people as less than human, as genetically inferior to the country's majority' (Elijah, 2000: 54).

The Convent women recreate themselves by the help of Connie who renames herself 'Consolata'. This gesture symbolizes her effort to reconstruct her identity as she wishes. She and other Convent women know that creating an earthly paradise is possible as long as individuals especially black women acknowledge the necessity of African American and black feminist tenets in their lives, and as long as they believe in the following sentence of the Declaration of Independence that says:

All men are created equal, that they are endowed by their Creator with certain inalienable Rights, that among these are Life, Liberty and the pursuit of Happiness. 
Finally Paradise depicts the need of the US community to find a common meaning despite the diversity of people forming it in order to protect its most unprotected members, and the Convent women assertively believe the common meaning could be that freedom for both men and women can only be achieved when the society has no racial and gender discrimination.

\section{References}

[1] Beaulieu, Elizabeth, A. The Toni Morrison Encyclopedia. Connecticut: Greenwood Press, (2003).

[2] Collins, P. H. Black Feminist Thought: Knowledge, Consciousness, and the Politics of Empowerment. 2nd Edition. New York: Routledge,( 2000). 100

[3] Dalsgård, Katrine. "The One All-Black Town Worth the Pain: (African) American Exceptionalism, Historical Narration, and the Critique of Nationhood in Toni Morrison's Paradise''. African American Review, Vol. 35, No. 2. Summer, (2001). 233.

[4] Elijah, Anderson. "African American Class Structure, the Emerging Philadelphia."Annals of the American Academy of Political and Social Science, (2000). 568 -76.

[5] Ghasemi, Parvin. and Hajizadeh, Rasool. 'Demystifying the Myth of Motherhood: Toni Morrison's Revision of African-American Mother Stereotypes'.International Journal of Social Science and Humanity, Vol. 2, No. 6. (November, 2012). 478.

[6] Hooks, Bell. Ain't I A Woman? Black Women and Feminism. London: Pluto, (1982).

[7] Hooks, Bell. Black Looks: Race and Representation. Boston: South End Press, (1992).

[8] Hooks, Bell. Feminism is for Everybody. Cambridge, MA: South End, (2000). 64 -5.

[9] Hooks, Bell. Feminist Theory: From Margin to Center. Boston: South End Press, (2000).

[10] Hooks, Bell. "The Oppositional Gaze: Black Female Spectators." Black Looks: Race and Representation. Boston: South End, (1992). 115.

[11] Hooks, Bell. Talking Back: Thinking Feminist, Thinking Black. Boston: South End Press, (1989).

[12] Hooks, Bell. Teaching community: a Pedagogy of Hope. New York: Routledge, (2003).

[13] Hooks, Bell. Teaching to Transgress: Education as the Practice of Freedom. London: Routledge, (1994).

[14] Hooks, Bell. Yearning: Race, Gender, and Cultural Politics. Boston: South End Publication, (1990). 22.

[15] Jozwiak, Mermann, Elisabeth. 'Re-membering the body: Body politics in Toni Morrison's The Bluest Eye.' Lit: Literature Interpretation Theory. Volume 12, Issue 2. London: Taylor and Francis, (2001). 189.

[16] King, Jeannette. Women and the Word: Contemporary Women Novelists and the Bible. London: Macmillan, (2000).

[17] Kjelle, Marylou, Morano. African American Leaders, Henry Lois Gates, Jr. Philadelphia: Chelsea House Publishers, (2009).

[18] Krumholz, J., Linda. ''Reading and Insight in Toni Morrison's Paradise.' African American Review. Vol. 36, No. 1. Spring, (2002). 21.

[19] Meade, A, Teresa. and Wiesner-Hanks, E. Marry. A Companion to Gender History. New Gersey: Blackwell Publishing, (2004).

[20] Michael, Cornier, Magali. ''Re-Imagining Agency: Toni Morrison's Paradise". African American Review, Vol. 36, No. 4. (Winter, 2002). 643-661. 
[21] Morrison, Toni. Beloved. New York: Penguin, (1987).

[22] Morrison, Toni. The Bluest Eye. New York: Washington Square Press, (1970).

[23] Morrison, Toni. Paradise. New York: Alfred A. Knopf Publication, (1997).

[24] Morrison, Toni. Playing in the Dark: Whiteness and the Literary Imagination. Cambridge: Harvard University Press. P. 34. (1992).

[25] Morrison, Toni. ' 'Unspeakable Things Unspoken: The Afro-American Presence in American Literature." Michigan Quarterly Review 28, (1989). 1-34.

[26] Morrison, Toni, and Claudia, Brodsky, Lacour. eds. Birth of a Nation 'Hood: Gaze, Script and Spectacle in the O. J. Simpson Case. New York: Pantheon. (1997).

[27] Morrison, Toni. and McKay, Nellie. 'An Interview with Toni Morrison.' Contemporary Literature, University of Wisconsin Press. 24: 4, (1983). 413-429

[28] Raynor, Deidre J. and Butler, Johnnella E. "Morrison and the Critical Community."The Cambridge Companion to Toni Morrison. Ed. Justine Tally. Cambridge: Cambridge UP. (2007). 177.

[29] Romero, Channette. Creating the Beloved Community: Religion, Race, and Nation in Toni Morrison's "Paradise".African American Review.Vol. 39, No. 3. (Fall, 2005). 420.

[30] Tyson, Lois. Critical Theory Today: A User Friendly Guide. New York: Routledge. (2006).

[31] Walker, Alice. In Search of Our Mothers' Gardens: Womanist Prose. New York: Harcourt. (1983).

[32] Widdowson, Peter. The American Dream Refashioned: History, Politics and Gender in Toni Morrison's "Paradise". Journal of American Studies. Vol. 35, No. 2, Part 2: Warring in America: Encounters of Gender and Race, (Aug., 2001). 313- 335.

[33] Womack, S. Craig. Studies in American Indian Literatures, Volume 21, Number 4. (Winter, 2009). 20- 52. 